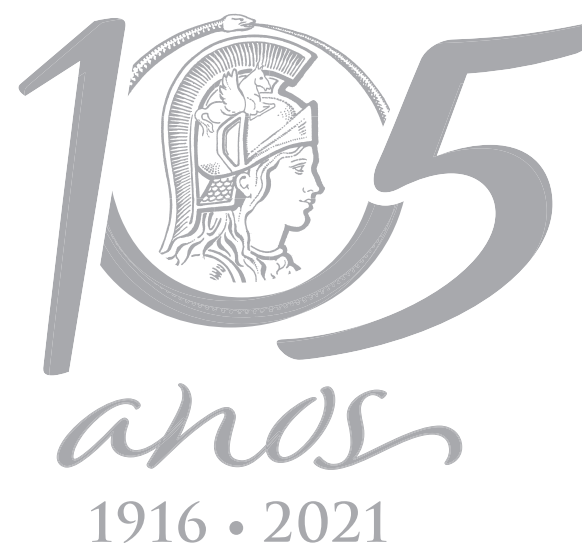

\title{
CELLULAR AND MOLECULAR BIOLOGY
}

\section{Cytogenotoxicity and protective effect of piperine and capsaicin on meristematic cells of Allium cepa $\mathrm{L}$.}

\author{
MARCONDES S. DIAS, ERASMO P.V. JUNIOR, BIANCA C. DOS SANTOS, FRANCIELLE
} A. MARTINS, PEDRO M. DE ALMEIDA \& ANA P. PERON

\begin{abstract}
Piperine and capsaicin are important molecules with biological and pharmacological activities. This study aimed to evaluate the cytogenotoxic and protective effect of piperine and capsaicin on Allium cepa cells. A. cepa roots were exposed to negative (2\% Dimethylsulfoxide) and positive (Methylmethanesulfonate, MMS, $10 \mu \mathrm{g} /$ $\mathrm{mL}$ ) controls, and four concentrations $(25-200 \mu \mathrm{M})$ of piperine or capsaicin (alone) or associated before, simultaneously or after with the MMS. Only the lowest concentration of piperine $(25 \mu \mathrm{M})$ showed a protective effect because it was not genotoxic. Piperine and capsaicin were cytotoxic (50, 100 and $200 \mu \mathrm{M}$ ). Piperine (50 to $200 \mu \mathrm{M}$ ) caused a significant increase in the total average of chromosomal alterations of in A. cepa cells. For capsaicin, the genotoxic effect was dose-dependent with a significant increase for all concentrations, highlighting the significant presence of micronuclei and nuclear buds for the two isolates. In general, bioactive compounds reduced the total average of chromosomal alterations against damage caused by MMS, mainly micronuclei and/or nuclear buds. Therefore, the two molecules were cytotoxic and genotoxic at the highest concentrations, and did not have cytoprotective action, and the lowest concentration of piperine demonstrated important chemopreventive activity.
\end{abstract}

Key words: Bioactive compounds, mitotic index, chromosomal alterations, protection against cell damage.

\section{INTRODUCTION}

Peppers comprise groups of plants of the genera Piper and Capsicum (Salazar et al. 2016) and are among the main spices appreciated worldwide. Peppers are functional foods, as they have a potential medicinal application with protective and therapeutic action (Antonio et al. 2018, Rather \& Bhagat 2018). The chemoprotective potential of piperamides has already been observed in P. nigrum and P. longum (Lai et al. 2012, Grinevicius et al. 2017) and in some species of Capsicum there are many biologically active metabolites, such as capsaicinoids, capsinoids and carotenoids (Luo et al. 2011,
Bertão et al. 2016). Protection can result from the interaction of molecules with mutagenic agents in the intracellular and/or extracellular (desmutagenic) media and in the damage repair process (bioantimutagenic) (Santos et al. 2012, Asita et al. 2015, Andrade et al. 2016).

The detection of phytochemicals capable of modulating genotoxic, mutagenic and carcinogenic effects show satisfactory results for polyphenols, carotenoids, alkaloids, tannins (Li et al. 2018, Ribeiro et al. 2018, Sá et al. 2019). There are several studies using natural extracts of Piper and Capsicum for analysis of genotoxicity and antigenotoxicity, however, 
studies evaluating isolated molecules are more frequent, given the improvement of the methods for extraction of these compounds and access to these substances commercially (Bley et al. 2012, Rather \& Bhagat 2018).

Piperine (1-piperylpiperidine) is an alkaloid isolated mainly from $P$. nigrum, known as black pepper, but can also be found in other representatives of the family Piperaceae (Meghwal \& Goswami 2013). The structural characteristics of piperine are divided into three parts: (1) an aromatic ring with a methylenedioxy bridge, associated with the antioxidant and anti-tumor potential; (2) a conjugated dienone system, which performs lipophilic interactions with various molecular residues; and (3) a piperidine ring that creates an amide bond, responsible for insecticidal and anti-tumor actions, in addition to interacting with enzymatic systems, leading to biotransformation effects (Qu et al. 2015, Singh \& Choudhary 2015).

Capsaicin (8-methyl-N-vanillyl-6nonenamide) is an alkaloid/amide compound found in Capsicum fruit and can account for $1 \%$ of the mass of peppers (Fattori et al. 2016). Regarding the structure and activity of capsaicin, stand out the regions: (1) aromatic, responsible for most of the antioxidant activity; (2) amide bond, responsible for the effect of analgesia and antinociceptive activity, and (3) the aliphatic chain, related to analgesic activity and with an important role in the total polarity of the molecule, giving it a hydrophobic character (Huang et al. 2013).

Piperine and capsaicin also have an antiparasitic and immunomodulatory effect (Soutar et al. 2017, Vurmaz et al. 2019). In addition, studies on the antiproliferative, mutagenic/ genotoxic/protective and anti-apoptotic/proapoptotic effects have been carried out on different types of tumor cells, but these studies have contradictory results for both piperine and capsaicin (Singh \& Duggal 2009, Fattori et al. 2016). Toxicogenic and/or protective effects depend on the dose and the group of cells treated. Understanding the modulatory activity, finding effective concentrations that are safe for the body is especially important. Although the evaluation of genotoxicity/antigenotoxicity of piperine and capsaicin has been carried out in vitro and in vivo tests (Thiel et al. 2014, FernandezBedmar \& Alonso-Moraga 2016), studies that show their effects using chromosomal changes such as cytogenetic biomarkers are incipient and there are no reports on the biological effects of piperine and capsaicin in a plant test system. Thus, the present study can show whether the isolates interact with spindle fibers and / or with the DNA and whether they have a modulating effect against the mutagenic agent.

The test system for chromosomal changes in Allium cepa L. is widely cited in the literature as a bioindicator for the evaluation of cytotoxicity, genotoxicity and protective effect of chemical compounds, as it has rapid cell multiplication, large and few chromosomes, which allows better analysis of structural and numerical changes (Leme \& Marin-Morales 2009, Bonciu et al. 2018). Its low cost and agreement with other similar tests, which involve the manipulation and sacrifice of animals, justifies its extensive use in toxicogenetic bioassays (Eren \& Özata 2014). Besides that, it has a good correlation with cytotoxicity and genotoxicity tests in vitro or in vivo (Eren \& Özata 2014, Sá et al. 2019).

Considering the importance of piperine and capsaicin as spices used in gastronomy and popular medicine (Bley et al. 2012, Muhammad et al. 2018), the present study aimed to investigate the cytotoxic, genotoxic, protective or modulating effects against the damages caused by methylmethanesulfonate, using the chromosomal alterations test in meristematic cells of A. cepa. 


\section{MATERIALS AND METHODS}

\section{Tested compounds}

Piperine $\geq 97 \%$ CAS (94-62-2), capsaicin $\geq 95 \%$ CAS (404-86-4) and Methylmethanesulfonate (MMS, CAS 66-27-3) were obtained from SigmaAldrich (St. Louis, MO, USA).

\section{DNA-damaging agent}

MMS was used to induce DNA damage in meristematic cells of $A$. cepa. MMS $(10 \mu \mathrm{g} / \mathrm{mL})$ is an alkylating agent with direct activity, inducing disturbances such as DNA breaks, bridges and chromosome loss, which are also expressed as micronuclei (Bianchi et al. 2016, Couto et al. 2019). MMS was used in A. cepa test because it has high genotoxicity at low concentrations. In addition, MMS shows less cytotoxic effect, allowing cells to continue the cell cycle and those chromosomal changes can be visualized in different phases of cell division (Bianchi et al. 2015).

\section{Allium cepa bioassay}

One hundred A. cepa (cv. Vale Ouro IPA-11) seeds per Petri dish were germinated with distilled water in an incubator (BOD SL $-224^{\circledR}$ ) under a $12 \mathrm{~h}$ photoperiod and temperature of $24 \mathrm{O} C$ for three days at the Genetics Laboratory (LABGENE) of the Center for Natural Sciences of UESPI, Teresina-PI. After germination, seeds with roots of approximately $1 \mathrm{~cm}$ were exposed to different treatments to assess the cytogenotoxicity and antigenotoxicity of the bioactive piperine and capsaicin, according to Nantes et al. (2014) and Couto et al. (2019).

In the genotoxicity test, seeds were transferred to the negative controls (NC) (Dimethylsulfoxide - 2\% DMSO in distilled water), solvent (SC) (distilled water), positive MMS I (Methylmethanesulfonate, $10 \mu \mathrm{g} / \mathrm{mL}$ dissolved in DMSO 2\%) and MMS II (dissolved only in distilled water) and for treatments with piperine or capsaicin in concentrations of 25, 50, 100 and 200 $\mu \mathrm{M}$ for $48 \mathrm{~h}$. The protective effect was performed by exposing the germinated seeds to piperine or capsaicin before, simultaneously or after the MMS, representing the pre, simultaneous and post treatments, respectively (Rocha et al. 2016). The pretreatment assesses demutagenic action, the simultaneous treatment assesses both demutagenic and bioantimutagenic activity and the posttreatment indicates bioantimutagenic action (Fedel-Miyasato et al. 2014, Felicidade et al. 2014).

The concentrations were previously determined from studies with the isolates and this range of concentrations is commonly tested on molecules with pharmaceutical potential. In addition, equal or similar concentrations are tested in chemotherapeutic trials dissolved in 2\% DMSO (Greenshields et al. 2015, Siddiqui et al. 2017).

After the treatments carried out, roots were fixed in Carnoy (3 ethanol: 1 acetic acid) for $6-8 \mathrm{~h}$ and stored at $-20^{\circ} \mathrm{C}$ until the slide was prepared. To mount the slides, roots were washed three times in distilled water for $5 \mathrm{~min}$ each and hydrolyzed at $60^{\circ} \mathrm{C}$ for $10 \mathrm{~min}$ in $1 \mathrm{~N}$ $\mathrm{HCl}$. After hydrolysis, roots were again washed in distilled water and transferred to amber glass flasks, containing the Schiff Reactive, where they remained in the dark for 2 hours. Roots were then washed, until the reagent was completely removed, transferred to slides, where they were crushed in a drop of $2 \%$ acetic carmine and mounted with Entellan ${ }^{\circledR}$ (107960; Merck Millipore) (Almeida et al. 2015).

Cytotoxicity, genotoxicityandantigenotoxicity were evaluated by counting 5,000 meristematic cells per treatment (500 cells/slides, with a total of 10 slides analyzed per treatment) under a light microscope (Zeiss Primo Star with Axiocam 105 color camera) at 400x magnification in the 
Soil Analysis Laboratory (LASO) of the Center for Agricultural Sciences (CCA) UFPI, Teresina-PI.

For each treatment, the mitotic index (MI, cytotoxicity) and mean chromosomal alteration (genotoxicity) resulting from aneugenic action (metaphase with chromosomal adhesion, C-metaphase, chromosomal loss, multipolar anaphase, binucleated cells) were evaluated for each treatment among others and/or clastogenic action (chromosomal fragments in metaphase or anaphase, chromosomal bridges and other alterations) (Leme \& Marin-Morales 2009). Cytotoxicity was also analyzed by the mean value of cells and cells in death process (CDP), which have characteristics such as: heteropicnotic nucleus and displaced to the periphery of the cell, vacuolization and swelling of the cytoplasm (Bianchi et al. 2010). To determine the MI, the number of cells in different phases of mitosis was divided by the total number of cells. For chromosome alterations, the number of alterations was divided by the total number of cells.

Protective effect was assessed by analyzing the percentage of damage reduction (\% DR) for each treatment with piperine or capsaicin, according to the following formula: \% DR $=[(a-b) /(a-c)] \times 100$ Where: $a=$ average of MMS chromosomal alterations; $b=$ average of chromosomal alterations in each treatment and $\mathrm{C}=$ average of chromosomal alterations in the NC) (Waters 1990).

\section{Data analysis}

Data were analyzed using the Kruskal-Wallis non-parametric test, followed by the StudentNewman-Keuls a posteriori test $(p<0.05)$, in the BioEstat 5.3 software (Ayres \& Ayres 2007), for comparison between the means of the controls and groups treated.

\section{RESULTS}

\section{Cytogenotoxicity of piperine and capsaicin}

Piperine and capsaicin were cytotoxic at concentrations from 50 to $200 \mu \mathrm{M}$, since there was a significant reduction in the mitotic index (MI) of the meristematic cells of $A$. cepa in relation to the NC, being dose dependent when exposed to capsaicin. Piperine and capsaicin significantly reduced the prophases (50 to $200 \mu \mathrm{M})$. Additionally, the lower percentage of prophases in capsaicin resulted in a significant reduction in the other phases of the $A$. cepa cell cycle, mainly in $200 \mu \mathrm{M}$ (Table I).

A. cepa cells in death process (CDP) were not significant when compared to the NC, however there was an increase in CDP in all concentrations of piperine and at the lowest (25 $\mu \mathrm{M})$ and higher $(200 \mu \mathrm{M})$ of capsaicin, which may have contributed to the cytotoxic effect (Table I, Figure 1p).

Piperine caused a significant increase in the total average of chromosomal alterations (genotoxic effect) at concentrations of 50 to $200 \mu \mathrm{M}$ in A. cepa cells when compared to NC. For capsaicin, the genotoxic effect was dose-dependent with a significant increase for all concentrations (Table I). Piperine and capsaicin caused different types of chromosomal alterations and normal cells: a) normal interphase; b) normal prophase; c) normal metaphase; d) normal anaphase; e) normal telophase; f) micronucleus (arrow); g) interphase with nuclear bud; h) chromosomal breaks (arrow); i) chromosomal adherence; j) C-metaphase; k) chromosomal loss (arrow); l) chromosomal bridge (arrow) and chromosomal break (arrow head); m) multipolar anaphase; n) binucleated cell; o) nuclear alteration; p) cells under death process (heteropicnotic nucleus displaced for cell periphery; vacuolization and cytoplasm swelling) (Table II, Figure 1a-p), but 

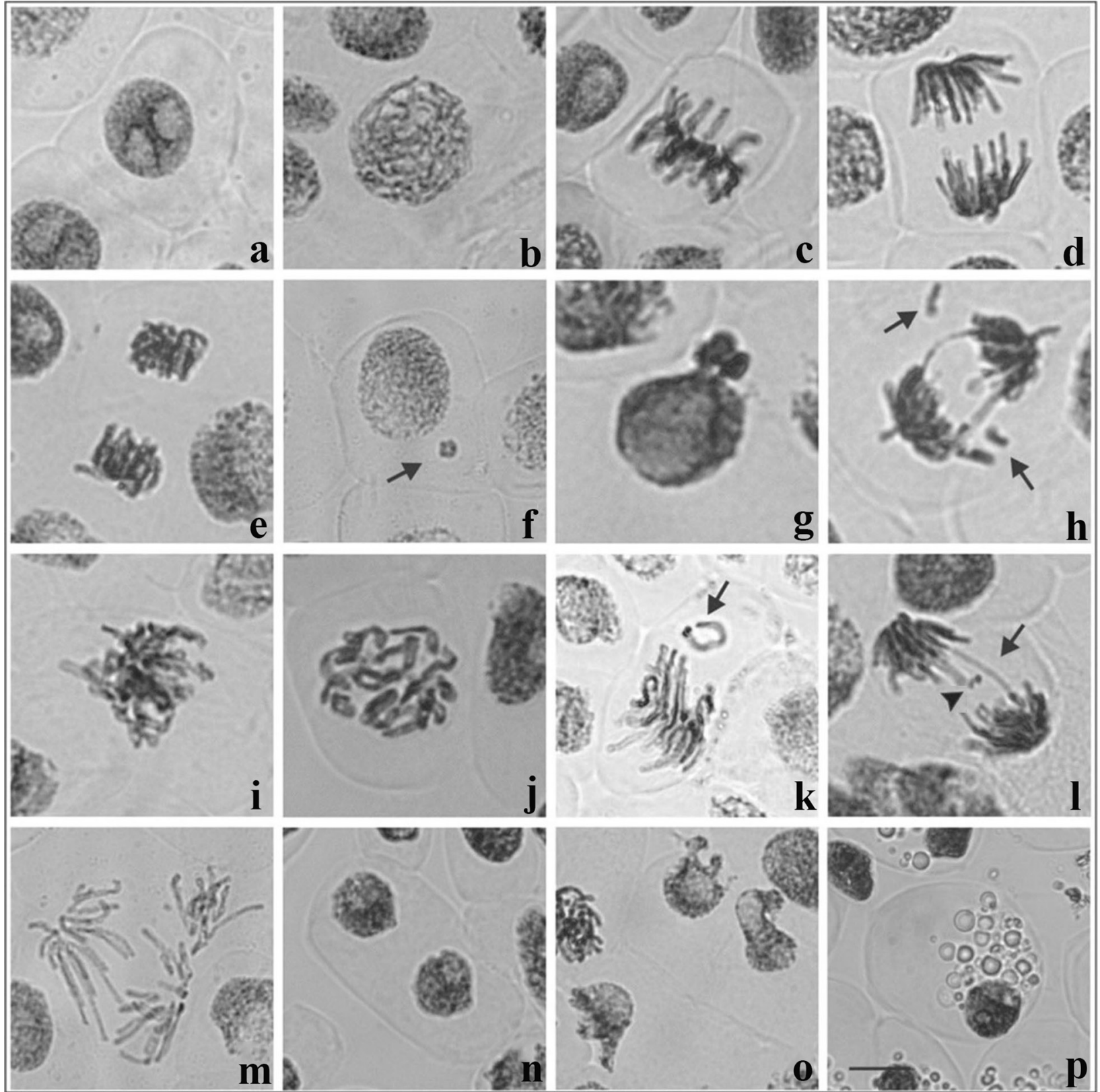

Figure 1. Chromosomal and nuclear alterations observed by the analysis of meristematic cells from Allium cepa roots. a) normal interphase. b) normal prophase. c) normal metaphase. d) normal anaphase. e) normal telophase. f) micronucleus (arrow). g) interphase with nuclear bud. h) chromosomal breaks (arrow). i) chromosomal adherence. j) C-metaphase. k) chromosomal loss (arrow). l) chromosomal bridge (arrow) and chromosomal break (arrow head). m) multipolar anaphase. $n$ ) binucleated cell. o) nuclear alteration. $p$ ) cells under death process (heteropicnotic nucleus displaced for cell periphery; vacuolization anda cytoplasm swelling). Bar: $10 \mu \mathrm{m}$ (for all images). All chromosomal changes were observed for piperine and capsaicin, except multipolar anaphase for capsaicin. 
Table I. Phases of mitosis, mitotic index, cells in death process (CDP) and total chromosomal alterations in meristematic cells of $A$. cepa exposed to different concentrations of piperine or capsaicin.

\begin{tabular}{|c|c|c|c|c|c|c|c|}
\hline \multirow{2}{*}{$\begin{array}{l}\text { Treatment } \\
\qquad(\mu \mathrm{M})\end{array}$} & \multicolumn{4}{|c|}{ Phases of mitosis (\%) } & \multirow{2}{*}{$\begin{array}{c}\text { Mitotic Index } \\
\text { (\%) }\end{array}$} & \multirow{2}{*}{$\begin{array}{l}\text { CDP } \\
(\%)\end{array}$} & \multirow{2}{*}{$\begin{array}{c}\text { Chromosomal } \\
\text { alteration }\end{array}$} \\
\hline & Prophase & Metaphase & Anaphase & Telophase & & & \\
\hline NC & $15.93 \pm 0.87$ & $1.33 \pm 0.75$ & $1.62 \pm 0.60$ & $0.98 \pm 0.34$ & $19.86 \pm 1.16$ & $0.04 \pm 0.12$ & $4.13 \pm 2.28$ \\
\hline MMS I & $10.57 \pm 1.50^{\star *}$ & $1.16 \pm 0.51$ & $1.09 \pm 0.46$ & $0.67 \pm 0.50$ & $14.09 \pm 1.96^{\star \star}$ & $0.77 \pm 1.80$ & $59.52 \pm 13.34^{* *}$ \\
\hline \multicolumn{8}{|c|}{ Piperine } \\
\hline 25 & $15.38 \pm 0.84$ & $1.36 \pm 0.46$ & $0.97 \pm 0.39$ & $1.21 \pm 0.45$ & $18.93 \pm 1.21$ & $0.08 \pm 0.24$ & $6.63 \pm 3.23$ \\
\hline 50 & $14.13 \pm 1.05^{\star}$ & $1.46 \pm 0.49$ & $1.44 \pm 0.33$ & $1.08 \pm 0.46$ & $18.11 \pm 1.06^{\star}$ & $0.51 \pm 1.29$ & $11.93 \pm 2.69^{\star *}$ \\
\hline 100 & $12.90 \pm 1.42^{\star \star}$ & $1.31 \pm 0.79$ & $1.01 \pm 0.52$ & $1.01 \pm 0.52$ & $16.22 \pm 1.94^{\star \star}$ & $0.27 \pm 0.60$ & $11.63 \pm 6.44^{*}$ \\
\hline 200 & $14.27 \pm 0.84^{*}$ & $1.23 \pm 0.51$ & $1.26 \pm 0.59$ & $1.10 \pm 0.67$ & $17.85 \pm 0.81^{*}$ & $0.47 \pm 1.03$ & $15.05 \pm 3.79^{* *}$ \\
\hline \multicolumn{8}{|c|}{ Capsaicin } \\
\hline 25 & $14.39 \pm 0.61$ & $1.24 \pm 0.38$ & $1.02 \pm 0.42^{\star}$ & $1.43 \pm 0.64$ & $18.08 \pm 0.97$ & $0.13 \pm 0.40$ & $13.31 \pm 9.71^{\star}$ \\
\hline 50 & $13.00 \pm 0.91^{*}$ & $1.05 \pm 0.39$ & $0.99 \pm 0.37^{\star}$ & $1.39 \pm 0.37$ & $16.42 \pm 1.38^{*}$ & $0.02 \pm 0.06$ & $14.55 \pm 3.46^{* *}$ \\
\hline 100 & $9.37 \pm 1.85^{\star \star}$ & $0.93 \pm 0.41$ & $0.81 \pm 0.47^{\star \star}$ & $0.79 \pm 0.49$ & $11.90 \pm 2.12^{\star \star}$ & $0.00 \pm 0.00$ & $15.36 \pm 4.94^{\star *}$ \\
\hline 200 & $4.64 \pm 2.55^{\star \star}$ & $0.15 \pm 0.22^{* *}$ & $0.17 \pm 0.25^{\star \star}$ & $0.24 \pm 0.33^{* *}$ & $5.21 \pm 3.05^{\star *}$ & $1.74 \pm 2.30$ & $16.78 \pm 6.73^{\star \star}$ \\
\hline
\end{tabular}

Data are means \pm SD (Standard Deviation). NC: Negative Control (Dimethylsulfoxide - $2 \%$ DMSO in distilled water). MMS I: $10 \mu \mathrm{g} /$ $\mathrm{mL}$ of Methylmethanesulfonate dissolved in DMSO 2\%. *Significant by Kruskal-Wallis test with a posteriori Student-NewmanKeuls test ( $p<0.05 ;{ }^{* *} p<0.01$ ) when compared to NC. Data are for 5,000 cells/treatment. The DMSO $2 \%$ was used as a negative control, but how the results were statistical identical to solvent (distilled water), the data using water were omitted. The MMS I and MMS II (dissolved only in distilled water) also were statistical identical, the data using MMS II were omitted.

only micronuclei (MN) and nuclear buds (NB) were significant (50 to $200 \mu \mathrm{M}$ ) in the piperine treatment. In capsaicin, the same changes were significant at all concentrations and chromosomal adherence was significant at concentrations of 50 and $100 \mu \mathrm{M}$.

\section{Modulation of cell damage by piperine and capsaicin}

As for the modulatory effect, there was no significant difference in $\mathrm{MI}$ and CDP in the three protocols (pre, simultaneous and posttreatment) exposed to piperine or capsaicin in relation to MMS I. Further, in capsaicin there were significant reductions in $\mathrm{MI}$ in the pre (100 and $200 \mu \mathrm{M}$ ), simultaneous (25 and $100 \mu \mathrm{M}$ ) and posttreatment $(200 \mu \mathrm{M})$ (Table III).

As for the different phases of mitosis, cells treated with piperine or capsaicin showed no significant difference in relation to MMS I in the three protocols. Further, in capsaicin, there was a reduction in prophases, metaphases and anaphases in the three protocols, and telophases only in the posttreatment (Table III). The observed results showed that piperine or capsaicin was not able to neutralize the cytotoxic action of MMS I.

A significant reduction in the total average of chromosomal alterations in A. cepa when exposed to piperine was verified in the pre (57.93 to $85.66 \%$ ), simultaneous (58.71 to $74.07 \%$ ) and posttreatment (54.38 to 64.16\%) for all concentrations in relation to MMS I. In capsaicin, the reduction of chromosomal alterations was also observed in the pre (70.39 to $86.21 \%$ ) and simultaneous (36.36 to 51.89\%) for all concentrations, while in the posttreatment, only the highest concentration $(200 \mu \mathrm{M})$ had the reduction (35.84\%). These results reinforce the interaction of piperine or capsaicin with MMS, modulating genotoxic action of MMS, however there was no protective effect (except for the 
lowest concentration of piperine), since these molecules alone were genotoxic (Table III).

The significant reduction in MN and/or NB was verified in all concentrations of the pre and simultaneous treatments in relation to MMS I when exposed to piperine or capsaicin. In the posttreatment, there was also a reduction in the same changes in all concentrations with piperine and for capsaicin occurred only in the highest concentration (Table IV).

\section{DISCUSSION}

The cytotoxic effect of piperine and capsaicin may be related to a significant reduction in prophases (50 to $200 \mu \mathrm{M}$ ). The lower percentage of prophases in capsaicin resulted in a significant decrease in the other phases of the A. cepa cell cycle, mainly in $200 \mu \mathrm{M}$ (Table I). The observed results are reinforced by previous studies showing the cytotoxicity of piperine or capsaicin in concentrations equal to and/or similar to the present study, which promoted the arrest of tumor cells in G1 (Ouyang et al. 2013, Fofaria et al. 2014) and/or G2 / M (Yaffe et al. 2013, Greenshields et al. 2015, Zhang et al. 2015, Siddiqui et al. 2017).

An increase in CDP in all concentrations of piperine and at the lowest and highest concentrations of capsaicin may also have contributed to the cytotoxic effect. Similar results were observed in tumor cells treated with piperine or capsaicin, which caused oxidative stress by reactive oxygen species (ROS) (Yaffe et al. 2013), reactive nitrogen species, inhibition of NADH-oxidoreductase (an enzyme that stimulates cell activity and proliferation) and rupture of the mitochondrial membrane permeability (Pramanik et al. 2011, Qian et al. 2016, Cho et al. 2017).




Table III. Phases of mitosis, mitotic index, cells in death process (CDP) and total chromosomal alterations and percentage of damage reduction (\%DR) in meristematic cells of $A$. cepa exposed to different concentrations of piperine or capsaicin.

\begin{tabular}{|c|c|c|c|c|c|c|c|c|}
\hline \multirow{2}{*}{$\begin{array}{c}\text { Treatment } \\
\quad(\mu \mathrm{M})\end{array}$} & \multicolumn{4}{|c|}{ Phases of mitosis (\%) } & \multirow[b]{2}{*}{$\begin{array}{c}\text { Mitotic } \\
\text { index }(\%)\end{array}$} & \multirow[b]{2}{*}{$\operatorname{CDP}(\%)$} & \multirow{2}{*}{$\begin{array}{c}\text { Total } \\
\text { chromosomal } \\
\text { alterations }\end{array}$} & \multirow[b]{2}{*}{ \%DR } \\
\hline & Prophase & Metaphase & Anaphase & Telophase & & & & \\
\hline NC & $\begin{array}{l}15.93 \pm \\
0.87^{++}\end{array}$ & $1.33 \pm 0.75$ & $1.62 \pm 0.60$ & $0.98 \pm 0.34$ & $19.86 \pm 1.16^{++}$ & $0.04 \pm 0.12$ & $4.13 \pm 2.28^{++}$ & - \\
\hline MMS I & $10.57 \pm 1.50$ & $1.16 \pm 0.51$ & $1.09 \pm 0.46$ & $0.67 \pm 0.50$ & $14.09 \pm 1.96$ & $0.77 \pm 1.80$ & $59.52 \pm 13.34$ & - \\
\hline \multicolumn{9}{|c|}{$\begin{array}{l}\text { Pre-treatment } \\
\text { Piperine + MMS I }\end{array}$} \\
\hline 25 & $11.60 \pm 1.08$ & $1.10 \pm 0.47$ & $1.00 \pm 0.28$ & $1.00 \pm 0.44$ & $14.70 \pm 1.66$ & $1.03 \pm 1.42$ & $27.43 \pm 5.29^{+}$ & 57.93 \\
\hline 50 & $11.24 \pm 1.06$ & $0.75 \pm 0.31^{+}$ & $0.77 \pm 0.40$ & $1.01 \pm 0.45$ & $13.78 \pm 1.33$ & $0.02 \pm 0.06$ & $15.06 \pm 5.44^{++}$ & 80.27 \\
\hline 100 & $10.80 \pm 0.49$ & $1.18 \pm 0.48$ & $0.77 \pm 0.28$ & $0.85 \pm 0.43$ & $13.60 \pm 0.88$ & $0.24 \pm 0.43$ & $13.39 \pm 4.33^{++}$ & 83.28 \\
\hline 200 & $10.42 \pm 0.85$ & $0.90 \pm 0.39$ & $0.66 \pm 0.36^{+}$ & $0.56 \pm 0.32$ & $12.53 \pm 1.06$ & $0.45 \pm 0.84$ & $12.07 \pm 2.83^{++}$ & 85.66 \\
\hline \multicolumn{9}{|c|}{$\begin{array}{l}\text { Simultaneous treatment } \\
\text { Piperine + MMS I }\end{array}$} \\
\hline 25 & $9.12 \pm 2.36$ & $0.13 \pm 0.40$ & $1.03 \pm 0.38$ & $0.66 \pm 0.32$ & $11.93 \pm 2.27$ & $0.22 \pm 0.70$ & $18.49 \pm 5.68^{++}$ & 74.07 \\
\hline 50 & $8.14 \pm 2.63$ & $1.15 \pm 0.47$ & $0.56 \pm 0.39^{+}$ & $0.91 \pm 0.38$ & $10.77 \pm 3.21$ & $0.43 \pm 0.70$ & $19.64 \pm 22.09^{++}$ & 72.00 \\
\hline 100 & $9.23 \pm 1.40$ & $1.24 \pm 0.65$ & $0.62 \pm 0.33^{+}$ & $0.90 \pm 0.37$ & 11. $99 \pm 1.60$ & $0.00 \pm 0.00$ & $22.09 \pm 6.65^{++}$ & 67.57 \\
\hline 200 & $8.13 \pm 2.12$ & $0.78 \pm 0.38$ & $0.69 \pm 0.38$ & $0.85 \pm 0.63$ & $10.62 \pm 2.28$ & $0.00 \pm 0.00$ & $27.00 \pm 8.19^{+}$ & 58.71 \\
\hline \multicolumn{9}{|c|}{$\begin{array}{l}\text { Post-treatment } \\
\text { Piperine + MMS I }\end{array}$} \\
\hline 25 & $8.79 \pm 1.29$ & $1.27 \pm 0.55$ & $1.22 \pm 0.39$ & $0.97 \pm 0.47$ & $12.25 \pm 2.04$ & $0.24 \pm 0.77$ & $23.98 \pm 7.96^{++}$ & 64.16 \\
\hline 50 & $10.40 \pm 0.97$ & $1.47 \pm 0.55$ & $1.20 \pm 0.50$ & $1.21 \pm 0.61$ & $14.26 \pm 1.32$ & $0.52 \pm 1.10$ & $25.04 \pm 6.39^{++}$ & 62.25 \\
\hline 100 & $9.55 \pm 1.04$ & $1.13 \pm 0.34$ & $1.12 \pm 0.45$ & $1.24 \pm 0.51$ & $13.03 \pm 1.55$ & $0.00 \pm 0.00$ & $28.49 \pm 8.27^{++}$ & 56.02 \\
\hline 200 & $9.35 \pm 1.02$ & $1.36 \pm 0.59$ & $0.96 \pm 0.50$ & $0.93 \pm 0.36$ & $12.59 \pm 1.41$ & $0.26 \pm 0.82$ & $29.40 \pm 7.05^{++}$ & 54.38 \\
\hline \multicolumn{9}{|c|}{$\begin{array}{l}\text { Pre-treatment } \\
\text { Capsaicin + MMS I }\end{array}$} \\
\hline 25 & $12.21 \pm 1.36$ & $0.82 \pm 0.43$ & $0.54 \pm 0.33^{+}$ & $0.41 \pm 0.29$ & $13.97 \pm 1.84$ & $0.00 \pm 0.00$ & $11.77 \pm 4.95^{++}$ & 86.21 \\
\hline 50 & $9.58 \pm 1.60$ & $0.46 \pm 0.28^{++}$ & $0.39 \pm 0.25^{++}$ & $0.39 \pm 0.25$ & $10.83 \pm 1.91$ & $0.25 \pm 0.55$ & $18.66 \pm 4.05^{++}$ & 73.77 \\
\hline 100 & $6.15 \pm 1.49^{+}$ & $0.37 \pm 0.39^{++}$ & $0.24 \pm 0.29^{++}$ & $0.40 \pm 0.28$ & $7.71 \pm 2.10^{++}$ & $0.08 \pm 0.19$ & $20.53 \pm 8.21^{++}$ & 70.39 \\
\hline 200 & $5.48 \pm 1.72^{++}$ & $0.44 \pm 0.28^{++}$ & $0.27 \pm 0.24^{++}$ & $0.34 \pm 0.29$ & $6.54 \pm 2.10^{++}$ & $1.01 \pm 1.58$ & $18.64 \pm 6.71^{++}$ & 73.80 \\
\hline \multicolumn{9}{|c|}{$\begin{array}{l}\text { Simultaneous treatment } \\
\text { Capsaicin + MMS I }\end{array}$} \\
\hline 25 & $8.16 \pm 1.91^{+}$ & $0.82 \pm 0.61$ & $0.34 \pm 0.19^{++}$ & $0.37 \pm 0.29$ & $9.69 \pm 1.96^{+}$ & $0.00 \pm 0.00$ & $39.38 \pm 6.93^{+}$ & 36.36 \\
\hline 50 & $9.87 \pm 1.61$ & $0.90 \pm 0.38$ & $0.42 \pm 0.25^{+}$ & $0.82 \pm 0.36$ & $12.00 \pm 1.23$ & $0.00 \pm 0.00$ & $35.01 \pm 15.16^{++}$ & 44.24 \\
\hline 100 & $8.71 \pm 1.99$ & $0.71 \pm 0.28^{+}$ & $0.24 \pm 0.15^{++}$ & $0.47 \pm 0.12$ & $10.19 \pm 2.02^{+}$ & $0.00 \pm 0.00$ & $30.78 \pm 7.63^{++}$ & 51.89 \\
\hline 200 & $8.95 \pm 1.91$ & $0.79 \pm 0.28$ & $0.39 \pm 0.31^{++}$ & $0.40 \pm 0.21$ & $10.53 \pm 1.95$ & $0.52 \pm 1.63$ & $37.07 \pm 11.46^{+}$ & 40.53 \\
\hline
\end{tabular}


Table III. Continuation.

\begin{tabular}{|c|c|c|c|c|c|c|c|c|}
\hline \multirow[b]{2}{*}{$\begin{array}{c}\text { Treatment } \\
(\mu \mathrm{M})\end{array}$} & \multicolumn{4}{|c|}{ Phases of mitosis (\%) } & \multirow{2}{*}{$\begin{array}{c}\text { Mitotic } \\
\text { index (\%) }\end{array}$} & \multirow[b]{2}{*}{$\operatorname{CDP}(\%)$} & \multirow{2}{*}{$\begin{array}{c}\text { Total } \\
\text { chromosomal } \\
\text { alterations }\end{array}$} & \multirow[b]{2}{*}{ \%DR } \\
\hline & Prophase & Metaphase & Anaphase & Telophase & & & & \\
\hline \multicolumn{9}{|c|}{$\begin{array}{l}\text { Post-treatment } \\
\text { Capsaicin + MMS I }\end{array}$} \\
\hline 25 & $9.09 \pm 1.68$ & $1.50 \pm 0.49$ & $0.68 \pm 0.24$ & $0.81 \pm 0.44$ & $12.09 \pm 2.10$ & $0.40 \pm 0.86$ & $50.18 \pm 11.64$ & 16.86 \\
\hline 50 & $8.76 \pm 1.54$ & $1.20 \pm 0.48$ & $0.84 \pm 0.39$ & $0.81 \pm 0.36$ & $11.61 \pm 1.80$ & $0.00 \pm 0.00$ & $61.60 \pm 13.31$ & -3.75 \\
\hline 100 & $8.19 \pm 1.03$ & $1.27 \pm 0.37$ & $0.85 \pm 0.43$ & $0.16 \pm 0.55^{+}$ & $11.49 \pm 1.76$ & $0.46 \pm 0.82$ & $57.46 \pm 9.74$ & 3.72 \\
\hline 200 & $4.45 \pm 1.54^{++}$ & $0.46 \pm 0.54^{+}$ & $0.21 \pm 0.28^{++}$ & $0.27 \pm 0.28$ & $5.38 \pm 2.39^{++}$ & $1.64 \pm 3.02$ & $39.67 \pm 14.23^{+}$ & 35.84 \\
\hline
\end{tabular}

Data are means \pm SD (Standard Deviation). NC: Negative Control (Dimethylsulfoxide - DMSO 2\% in distilled water). MMS I: 10 $\mu \mathrm{g} / \mathrm{mL}$ of Methylmethanesulfonate dissolved in $2 \%$ DMSO (positive control). Pre-treatment (piperine or capsaicin + MMS). Simultaneous treatment (piperine or capsaicin added simultaneously with MMS). Post-treatment (MMS + piperine or capsaicin). ${ }^{+}$Significant in the Kruskal-Wallis test with a posteriori Student-Newman-Keuls test $\left({ }^{+} p<0.05 ;{ }^{++} p<0.01\right)$ when compared to MMS I. The results refer to the analysis of 5,000 cells per treatment. The DMSO $2 \%$ was used as a negative control, but how the results were statistical identical to solvent (distilled water), the data using water were omitted. The MMS I and MMS II (dissolved only in distilled water) also were statistical identical, the data using MMS II were omitted.

Pro-oxidant action of piperine or capsaicin may have resulted in the genotoxic effect, as ROSs increase the risk of DNA damage, including the division of cells with unrepaired or poorly repaired damage, leading to mutations (Kehrer \& Klotz 2015). The genotoxic effect observed in piperine and capsaicin are, mainly, the result of significant MN and NB. The MN observed are due to clastogenic and/or aneugenic damage not repaired or erroneously repaired in parental cells, is easily observed in daughter cells as a structure similar to the main nucleus, but in a reduced size (Fernandes et al. 2007, Leme \& Marin-Morales 2009). NB may be related to the formation of $M N$, through the elimination of extra genetic material in the main nucleus of the cell, or it may be due to the aggregation of a delayed chromosome by the nuclear envelope, before being fully reincorporated into the main nucleus (Bianchi et al. 2015). While chromosomal adherences are a type of abnormality that involves the protein in the chromatin matrix and not necessarily the DNA itself; it can also be irreversible and lead to cell death (Fernandes et al. 2009).
Piperine and capsaicin are potential antimutagenic and anticarcinogenic compounds (Abo-Zeid \& Farghaly 2009, Fernandez-Bedmar \& Alonso-Moraga 2016). In this way, we sought to evaluate the protective or modulatory effect of both molecules on damage induced by MMS I in the pre, simultaneous and posttreatment protocols.

The two molecules are alkaloids, which have both antioxidant and pro-oxidant action (capable of generating free radicals) depending on the dose and the group of treated cells (Rather \& Bhagat 2018, Macáková et al. 2019). Probably, the molecules acted as pro-oxidants in the cells of A. cepa, potentiating the cytotoxic action of MMS I, mainly for capsaicin, which promoted significant reductions in the MI. According to Bianchi et al. (2016), ROS may be associated with decreased $\mathrm{MI}$ in $\mathrm{A}$. cepa cells, as they cause lipid peroxidation, changes in membrane fluidity and DNA damage. In response to these damages, there is usually a delay in the mitotic cycle, mainly in the G1 and/or G2 phases, to allow the cells to repair the damage induced before replicating their DNA and starting mitosis (Feng et al. 2010). 
Table IV. Chromosomal alterations in meristematic cells of $A$. cepa exposed to different concentrations of piperine or capsaicin.

\begin{tabular}{|c|c|c|c|c|c|c|c|c|c|c|}
\hline \multirow{2}{*}{$\begin{array}{l}\text { Treatment } \\
\qquad(\mu \mathrm{M})\end{array}$} & \multicolumn{10}{|c|}{ Chromosomal alteration } \\
\hline & MN & NB & CB & BC & CA & $\mathrm{Cm}$ & CL & $\mathrm{CBr}$ & MA & NA \\
\hline NC & $0.84 \pm 1.08^{++}$ & $+2.82 \pm 1.62^{++}$ & $0.00 \pm 0.00$ & $0.00 \pm 0.00$ & $0.10 \pm 0.31$ & $0.10 \pm 0.30$ & $0.19 \pm 0.39$ & $0.00 \pm 0.00$ & $0.10 \pm 0.31$ & $0.00 \pm 0.00$ \\
\hline MMS I & $33.56 \pm 7.66$ & $23.43 \pm 5.80$ & $0.46 \pm 0.64$ & $0.28 \pm 064$ & $0.38 \pm 0.50$ & $0.00 \pm 0.00$ & $0.84 \pm 1.01$ & $0.28 \pm 0.45$ & $0.10 \pm 0.31$ & $0.19 \pm 0.39$ \\
\hline \multicolumn{11}{|c|}{$\begin{array}{l}\text { Pre-treatment } \\
\text { Piperine + MMS I }\end{array}$} \\
\hline 25 & $13.31 \pm 4.31^{++}$ & $\begin{array}{l}12.23 \pm \\
2.88^{+ \pm}\end{array}$ & $0.38 \pm 0.67$ & $0.00 \pm 0.00$ & $0.10 \pm 0.31$ & $0.00 \pm 0.00$ & $0.85 \pm 0.54$ & $0.29 \pm 0.46$ & $0.18 \pm 0.39$ & $0.10 \pm 0.31$ \\
\hline 50 & $6.09 \pm 3.58^{++}$ & $+7.41 \pm 4.83^{++}$ & $0.74 \pm 0.74$ & $0.09 \pm 0.29$ & $0.18 \pm 0.38$ & $0.00 \pm 0.00$ & $0.09 \pm 0.27$ & $0.46 \pm 0.66$ & $0.00 \pm 0.00$ & $0.00 \pm 0.00$ \\
\hline 100 & $4.69 \pm 3.05^{++}$ & $+7.56 \pm 2.94^{++}$ & $0.39 \pm 0.50$ & $0.00 \pm 0.00$ & $0.37 \pm 0.65$ & $0.00 \pm 0.00$ & $0.19 \pm 0.40$ & $0.19 \pm 0.40$ & $0.00 \pm 0.00$ & $0.00 \pm 0.00$ \\
\hline 200 & $4.48 \pm 2.39^{++}$ & $6.47 \pm 2.92^{++}$ & $0.48 \pm 0.81$ & $0.00 \pm 0.00$ & $0.18 \pm 0.57$ & $0.00 \pm 0.00$ & $0.09 \pm 0.30$ & $0.38 \pm 0.67$ & $0.00 \pm 0.00$ & $0.00 \pm 0.00$ \\
\hline \multicolumn{11}{|c|}{$\begin{array}{l}\text { Simultaneous treatment } \\
\text { Piperine + MMS I }\end{array}$} \\
\hline 25 & $\begin{array}{l}11.09 \pm \\
4.40^{++}\end{array}$ & $6.65 \pm 4.38^{++}$ & $0.19 \pm 0.39$ & $0.00 \pm 0.00$ & $0.19 \pm 0.38$ & $0.10 \pm 0.30$ & $0.00 \pm 0.00$ & $0.18 \pm 0.39$ & $0.10 \pm 0.30$ & $0.00 \pm 0.00$ \\
\hline 50 & $8.95 \pm 4.71^{++}$ & $9.87 \pm 3.57^{++}$ & $0.28 \pm 0.48$ & $0.00 \pm 0.00$ & $0.36 \pm 0.63$ & $0.00 \pm 0.00$ & $0.00 \pm 0.00$ & $0.18 \pm 0.57$ & $0.00 \pm 0.00$ & $0.00 \pm 0.00$ \\
\hline 100 & $\begin{array}{c}10.55 \pm \\
4.75^{++}\end{array}$ & $\begin{array}{c}10.03 \pm \\
2.76^{++}\end{array}$ & $0.19 \pm 0.41$ & $0.00 \pm 0.00$ & $0.65 \pm 0.77$ & $0.00 \pm 0.00$ & $0.19 \pm 0.39$ & $0.48 \pm 0.82$ & $0.00 \pm 0.00$ & $0.00 \pm 0.00$ \\
\hline 200 & $\begin{array}{l}12.61 \pm \\
7.05^{++}\end{array}$ & $13.54 \pm 3.76$ & $0.28 \pm 0.63$ & $0.00 \pm 0.00$ & $0.00 \pm 0.00$ & $0.19 \pm 0.40$ & $0.28 \pm 0.45$ & $0.00 \pm 0.00$ & $0.00 \pm 0.00$ & $0.09 \pm 0.29$ \\
\hline \multicolumn{11}{|c|}{$\begin{array}{l}\text { Post-treatment } \\
\text { Piperine + MMS I }\end{array}$} \\
\hline 25 & $\begin{array}{l}13.86 \pm \\
6.05^{++} \\
\end{array}$ & $8.91 \pm 3.56^{+}$ & $0.09 \pm 0.29$ & $0.00 \pm 0.00$ & $0.66 \pm 0.45$ & $0.00 \pm 0.00$ & $0.00 \pm 0.00$ & $0.47 \pm 0.65$ & $0.00 \pm 0.00$ & $0.00 \pm 0.00$ \\
\hline 50 & $\begin{array}{l}13.32 \pm \\
2.82^{++}\end{array}$ & $11.05 \pm 4.62^{+}$ & $0.00 \pm 0.00$ & $0.00 \pm 0.00$ & $0.40 \pm 0.70$ & $0.08 \pm 0.26$ & $0.00 \pm 0.00$ & $0.19 \pm 0.40$ & $0.00 \pm 0.00$ & $0.00 \pm 0.00$ \\
\hline 100 & $\begin{array}{c}15.88 \pm \\
6.56^{++}\end{array}$ & $\begin{array}{l}11.67 \pm \\
3.96^{ \pm+}\end{array}$ & $0.00 \pm 0.00$ & $0.00 \pm 0.00$ & $0.57 \pm 0.67$ & $0.00 \pm 0.00$ & $0.10 \pm 0.31$ & $0.28 \pm 0.44$ & $0.00 \pm 0.00$ & $0.00 \pm 0.00$ \\
\hline 200 & $\begin{array}{c}16.24 \pm \\
6.20^{++} \\
\end{array}$ & $\begin{array}{c}12.63 \pm \\
6.20^{++} \\
\end{array}$ & $0.00 \pm 0.00$ & $0.00 \pm 0.00$ & $0.35 \pm 0.83$ & $0.00 \pm 0.00$ & $0.00 \pm 0.00$ & $0.18 \pm 0.39$ & $0.00 \pm 0.00$ & $0.00 \pm 0.00$ \\
\hline \multicolumn{11}{|c|}{$\begin{array}{l}\text { Pretreatment } \\
\text { Capsaicin + MMS I }\end{array}$} \\
\hline 25 & $5.67 \pm 2.22^{++}$ & $5.45 \pm 3.63^{++}$ & $0.10 \pm 0.31$ & $0.00 \pm 0.00$ & $0.17 \pm 0.37$ & $0.00 \pm 0.00$ & $0.09 \pm 0.29$ & $0.19 \pm 0.40$ & $0.00 \pm 0.00$ & $0.10 \pm 0.31$ \\
\hline 50 & $9.76 \pm 3.16^{+}$ & $7.79 \pm 2.61^{++}$ & $0.19 \pm 0.40$ & $0.00 \pm 0.00$ & $0.73 \pm 0.37$ & $0.00 \pm 0.00$ & $0.00 \pm 0.00$ & $0.19 \pm 0.39$ & $0.00 \pm 0.00$ & $0.00 \pm 0.00$ \\
\hline 100 & $8.13 \pm 5.64^{++}$ & $10.22 \pm 5.78^{+}$ & $0.59 \pm 1.88$ & $0.00 \pm 0.00$ & $0.75 \pm 1.08$ & $0.00 \pm 0.00$ & $0.28 \pm 0.62$ & $0.37 \pm 0.48$ & $0.10 \pm 0.31$ & $0.09 \pm 0.29$ \\
\hline 200 & $8.01 \pm 3.30^{++}$ & $9.60 \pm 4.30^{+}$ & $0.00 \pm 0.00$ & $0.09 \pm 0.28$ & $0.46 \pm 0.68$ & $0.00 \pm 0.00$ & $0.10 \pm 0.31$ & $0.10 \pm 0.31$ & $0.09 \pm 0.29$ & $0.10 \pm 0.31$ \\
\hline \multicolumn{11}{|c|}{$\begin{array}{l}\text { Simultaneous treatment } \\
\text { Capsaicin + MMS I }\end{array}$} \\
\hline 25 & $25.47 \pm 4.44$ & $12.31 \pm 3.84^{+}$ & $0.19 \pm 0.40$ & $0.00 \pm 0.00$ & $0.66 \pm 0.65$ & $0.10 \pm 0.31$ & $0.37 \pm 0.90$ & $0.09 \pm 0.29$ & $0.00 \pm 0.00$ & $0.19 \pm 0.40$ \\
\hline 50 & $\begin{array}{c}20.64 \pm \\
8.54^{+}\end{array}$ & $11.89 \pm 6.63^{+}$ & $0.68 \pm 0.65$ & $0.09 \pm 0.29$ & $0.76 \pm 0.89$ & $0.27 \pm 0.86$ & $0.39 \pm 0.81$ & $0.29 \pm 0.46$ & $0.00 \pm 0.00$ & $0.00 \pm 0.00$ \\
\hline 100 & $\begin{array}{c}19.07 \pm \\
5.80^{++}\end{array}$ & $\begin{array}{c}10.50 \pm \\
4.24^{ \pm+}\end{array}$ & $0.45 \pm 0.65$ & $0.00 \pm 0.00$ & $0.46 \pm 0.65$ & $0.00 \pm 0.00$ & $0.19 \pm 0.60$ & $0.00 \pm 0.00$ & $0.00 \pm 0.00$ & $0.09 \pm 0.30$ \\
\hline
\end{tabular}




\section{Table IV. Continuation.}

\begin{tabular}{|c|c|c|c|c|c|c|c|c|c|c|}
\hline \multirow{2}{*}{$\begin{array}{c}\text { Treatment } \\
\text { ( } \mu M)\end{array}$} & \multicolumn{10}{|c|}{ Chromosomal alteration } \\
\hline & MN & NB & CB & BC & CA & $\mathrm{Cm}$ & CL & $\mathrm{CBr}$ & MA & NA \\
\hline 200 & $20.59 \pm 8.21^{+}$ & $14.84 \pm 4.86$ & $0.39 \pm 0.69$ & $0.10 \pm 0.32$ & $0.86 \pm 1.05$ & $0.10 \pm 0.31$ & $0.10 \pm 0.31$ & $0.10 \pm 0.31$ & $0.00 \pm 0.00$ & $0.00 \pm 0.00$ \\
\hline \multicolumn{11}{|c|}{$\begin{array}{l}\text { Post-treatment } \\
\text { Capsaicin + MMS I }\end{array}$} \\
\hline 25 & $31.53 \pm 8.44$ & $17.16 \pm 4.47$ & $0.10 \pm 0.58$ & $0.09 \pm 0.30$ & $0.74 \pm 0.84$ & $0.20 \pm 0.63$ & $0.00 \pm 0.00$ & $0.18 \pm 0.38$ & $0.09 \pm 0.30$ & $0.00 \pm 0.00$ \\
\hline 50 & $42.56 \pm 11.74$ & $16.50 \pm 5.00$ & $0.10 \pm 0.31$ & $0.00 \pm 0.00$ & $0.81 \pm 0.67$ & $0.09 \pm 0.28$ & $0.91 \pm 1.03$ & $0.37 \pm 0.48$ & $0.09 \pm 0.28$ & $0.17 \pm 0.36$ \\
\hline 100 & $37.85 \pm 7.86$ & $17.35 \pm 2.11$ & $0.10 \pm 0.31$ & $0.10 \pm 0.32$ & $0.86 \pm 0.83$ & $0.18 \pm 0.38$ & $0.48 \pm 0.69$ & $0.55 \pm 0.63$ & $0.00 \pm 0.00$ & $0.00 \pm 0.00$ \\
\hline 200 & $\begin{array}{c}26.70 \pm \\
10.25\end{array}$ & $\begin{array}{c}11.82 \pm \\
6.16^{++}\end{array}$ & $0.00 \pm 0.00$ & $0.00 \pm 0.00$ & $0.28 \pm 0.46$ & $0.29 \pm 0.66$ & $0.28 \pm 0.64$ & $0.19 \pm 0.41$ & $0.10 \pm 0.31$ & $0.00 \pm 0.00$ \\
\hline
\end{tabular}

Data are means \pm SD (Standard deviation). NC: Negative Control (Dimethylsulfoxide - DMSO 2\% in distilled water). MMS I: 10 $\mu \mathrm{g} / \mathrm{mL}$ of Methylmethanesulfonate dissolved in DMSO 2\%. MN: Micronucleus. NB: Nuclear Bud. CB: Chromosomal Breaking. BC: Binucleated Cell. CA: Chromosomal Adherence. Cm: C-metaphase. CL: Chromosomal Loss. CBr: Chromosomal Bridge. MA: Multipolar Anaphase. NA: Nuclear Alteration. Pre-treatment (piperine or capsaicin + MMS). Simultaneous treatment (piperine or capsaicin added simultaneously with MMS). Post-treatment (MMS + piperine or capsaicin). ${ }^{+}$Significant in the Kruskal-Wallis test with a posteriori Student-Newman-Keuls test $\left({ }^{+} p<0.05 ;{ }^{++} p<0.01\right)$ when compared to MMS I. The results refer to the analysis of 5,000 cells per treatment. The DMSO $2 \%$ was used as a negative control, but how the results were statistical identical to solvent (distilled water), the data using water were omitted. The MMS I and MMS II (dissolved only in distilled water) also were statistical identical, the data using MMS II were omitted.

In general, the tested compounds modulated the genotoxic effect of MMS I. In the pre, the isolated compound (piperine or capsaicin) may have interacted directly with MMS I in the intracellular environment in A. cepa cells. For the simultaneous, the reduction in damage to the cell can be a result of both the demutagenic and bioantimutagenic action (Nantes et al. 2014) by the tested bioactive agents. In posttreatment, piperine also promoted a reduction in damage induced by MMS I by the bioantimutagenic action, which acts in DNA repair mechanisms, inducing the reversion of the mutagenic effect and/or preventing the fixation of mutations (Dametto et al. 2017). In capsaicin, a similar result for the posttreatment was observed only in the highest concentration. These results reinforce the interaction of piperine or capsaicin, modulating the genotoxic action of MMS, however there was no protective effect, since these molecules alone were genotoxic with a significant production of MN and NB. Moreover, the \%RD was also a result of a significant reduction of the same alterations, reinforcing the possible interaction between isolates with MMS I.

Only the lowest concentration of piperine (25 $\mu \mathrm{M})$ was not genotoxic and showed a protective effect in all protocols (pre, simultaneous, and post), showing demutagenic and bioantimutagenic action, which increases the interest in further studies on this concentration as a chemoprotective. Other studies have also shown satisfactory results regarding the protective effect of piperine in the test for chromosomal changes in mouse bone marrow cells induced by cyclophosphamide and mitomycin C (Wongpa et al. 2007, Abo-Zeid \& Farghaly 2009). Piperine also decreased the genotoxic (comet assay) and mutagenic (test micronucleus) effect induced by aflatoxins in chickens (Cardoso et al. 2016). The cytochrome P450 enzyme is responsible for $50 \%$ of the metabolism of therapeutic agents, and the comparison of the presence of this enzyme complex leads to the conclusion that plants have a lower concentration of antioxidant enzymes compared to mammals and insects (Leme \& Marin-Morales 2009, Rocha et al. 2016). 
MMS was used in the present study as a DNA damage inducer in the A. cepa assay. There are two main mechanisms by which this compound can act. The first is its known capacity for alkylation and methylation, which can cause breaks in the double strand of DNA and inhibition of the replication fork (Chatterjee \& Walker 2017). The second is its induction of high levels of oxidative stress, which can lead to apoptosis, cell death and DNA damage (Lackinger et al. 2001, Jiang et al. 2016). Studies demonstrate the ability to deplete GlutathioneS-transferase (Liu et al. 1996) and Glutathione (Siddique et al. 2019) levels by MMS, which impairs cellular antioxidant defenses and leads to the accumulation of ROS generated as byproducts of normal cellular metabolism (Raza 2011).

Piperine or capsaicin probably neutralized and/or modulated the action of MMS I by the two mechanisms mentioned, since the direct genotoxic action of MMS I was reduced in the protocols used. Moreover, piperine or capsaicin may also have acted by neutralizing the ROS resulting from the action of MMS, since the isolates are alkaloids and have antioxidant activities, neutralizing the action of free radicals (Kaur \& Arora 2015, Tsoi et al. 2015).

Based on the results obtained in the present study, piperine and capsaicin showed a cytotoxic effect, except for the lowest concentration, associated mainly with the reduction of prophases in A. cepa, and genotoxic effect with emphasis on $M N$ and NB, except for the lowest concentration of piperine. Even with no cytoprotective effect, the analyzed compounds reduced chromosomal alterations ( $M N$ and NB) in most protocols and concentrations, which reinforces the possible interaction with MMS. However, only the lowest concentration of piperine $(25 \mu \mathrm{M})$ was not genotoxic and showed a protective effect in all protocols, while the other concentrations of the tested molecules alone were genotoxic. Thus, the lowest concentration of piperine demonstrated important chemopreventive activity, which is indirectly correlated with the prevention and/ or treatment of genetic diseases, such as cancer. Nevertheless, further studies are required to elucidate possible mechanisms of interaction between biocompounds and MMS.

\section{Acknowledgments}

The Universidade Federal do Piauí (UFPI) and the Coordenação de Aperfeiçoamento Pessoal de Nivel Superior (CAPES). The authors would like to thank the Universidade Estadual do Piauí for providing some of the necessary laboratory facilities for this work.

\section{REFERENCES}

ABO-ZEID MAM \& FARGHALY AA. 2009. The Anti-mutagenic activity of piperine against Mitomycine $C$ induced sister chromatid exchanges and chromosomal aberrations in mice. Nat Sci 7: 72-78.

ALMEIDA PM, ARAÚJO SS, MARIN-MORALES MA, BENKO-ISEPPON AM \& BRASILEIRO-VIDAL AC. 2015. Genotoxic potential of the latex from cotton-leaf physicnut (Jatropha gossypiifolia L.). Gen Mol Biol 100: 93-100.

ANDRADE AF, ALVES JM, CORREAA MB, CUNHA WR, VENEZIANI RCS \& TAVARES DC. 2016. In vitro cytotoxicity, genotoxicity and antigenotoxicity assessment of Solanum lycocarpum hydroalcoholic extract. Pharm Biol 11: 2786-2790.

ANTONIO AS, WIEDEMANN LSM \& JUNIOR VV. 2018. The genus Capsicum: a phytochemical review of bioactive secondary metabolites. Royal Soc Chem 8: 25767-15784.

ASITA O, HEISI DH \& TJALE T. 2015. Modulation of mutageninduced genotoxicity by two lesotho medicinal plants in Allium cepa L. Environ. Nat Resour Res 5: 37-55.

AYRES M \& AYRES MJ. 2007. BioEstat 5.3 - aplicações estatísticas nas áreas das ciências biomédicas. Sociedade Civil Mamirauá: Belém, 364 p.

BERTÃO MR, MORAES MC, PALMIERI DA, SILVA LP \& SILVA RMG. 2016. Cytotoxicity, genotoxicity and antioxidant activity of extracts from Capsicum spp. Res J Med Plants 10: 265-275.

BIANCHI J, ESPINDOLA ELG \& MARIN-MORALES MA. 2010. Genotoxicity and mutagenicity of water samples from 
the Monjolinho River (Brazil) after receiving untreated effluents. Ecotoxicol Environ Saf 74: 826-833.

BIANCHI J, FERNANDES TCC \& MARIN-MORALES MA. 2016. Induction of mitotic and chromosomal abnormalities on Allium cepa cells by pesticides imidacloprid and sulfentrazone and the mixture of them. Chemosphere 144: 475-483.

BIANCHI J, MANTOVANI MS \& MARIN-MORALES MA. 2015. Analysis of the genotoxic potential of low concentrations of Malathion on the Allium cepa cells and rat hepatoma tissue culture. J Environ Sci 36: 102-111.

BLEY K, BOORMAN G, MOHAMMAD B, MCKENZIE D \& BABBAR SA. 2012. A comprehensive review of the carcinogenic and anticarcinogenic potential of capsaicin. Toxicol Pathol 40: 847-873.

BONCIU E, FIRBASP, FONTANETTI CS, WUSHENG J, KARAISMAILOĞLU MC, LIU DS \& SCHIFF S. 2018. An evaluation for the standardization of the Allium cepa test as cytotoxicity and genotoxicity assay. Caryologia 71: 191-209.

CARDOSO VS, VERMELHO AB, LIMA CAR, OLIVEIRA JM, LIMA MEF, SILVA LHP \& DANELLI MDGM. 2016. Antigenotoxic effect of piperine in broiler chickens intoxicated with Aflatoxin B1. Toxins 8: 1-14.

CHATTERJEE N \& WALKER GC. 2017. Mechanisms of DNA damage, repair, \& mutagenesis. Environ Mol Mutagen 58: 235-263.

CHO SC, LEE H \& CHOI BY. 2017. An updated review on molecular mechanisms underlying the anticancer effects of capsaicin. Food Scien Biotechnol 26: 1-13.

COUTO A, ARAÚJO I, LOPES A, COUTO L, SANTOS P, SOUSA R, MARTINS F \& ALMEIDA PM. 2019. Antimutagenic activity and identification of antioxidant compounds in the plant Poincianella bracteosa (Fabaceae). Rev de Biol Trop 67: 1103-1113.

DAMETTO AC, AGUSTONI D, MOREIRA TF, PLAZA CV, PRIETO AM, SILVA TG \& SOARES CP. 2017. Chemical composition and in vitro chemoprevention assessment of Eugenia jambolana Lam. (Myrtaceae) fruits and leaves. J Funct Foods 36: 490-502.

EREN Y \& ÖZATA A. 2014. Determination of mutagenic and cytotoxic effects of Limonium globuliferum aqueous extracts by Allium, Ames, \& MTT tests. Braz J Pharmacog 24: $51-59$.

FATTORI V, HOHMANN MS, ROSSANEIS AC, PINHO-RIBEIRO FA \& VERRI WA. 2016. Capsaicin: Current understanding of its mechanisms and therapy of pain and other pre-clinical and clinical uses. Molecules 21: e844.
FEDEL-MIYASATO LES, FORMAGIO ASN, AUHAREK SA, KASSUYA CAL, NAVARRO SD, CUNHA-LAURA AL \& OLIVEIRA RJ. 2014. Antigenotoxic and antimutagenic effects of Schinus terebinthifolius Raddi in Allium cepa and Swiss mice: A comparative study. Gen Mol Res 13: 3411-3425.

FELICIDADE I, LIMA JD, PESARINI JR, MONREAL ACD, MANTOVANI MS, REGINA L \& RIBEIRO RJO. 2014. Mutagenic and antimutagenic effects of crude hydroalcoholic extract of Rosemary (Rosmarinus officinalis L.) on cultured. Vedic Res Internat Phytom 2: 30-39.

FENG B, GUO YM, HUANG CG, LI L, CHEN RH \& JIAO BH. 2010. 2-epi-2-O-Acetylthevetin $B$ extracted from seeds of Cerbera manghas L. induces cecly arrest and apoptosis in human hepatocellular carcinoma HepG2 cells. Chem Biol Interact 183: 142-153.

FERNANDES TCC, MAZZEO DEC \& MARIN-MORALES MA. 2007. Mechanism of micronuclei formation in polyploidizated cells of Allium cepa exposed to trifluralin herbicide. Pest Biochem Physiol 88: 252-259.

FERNANDES TCC, MAZZEO DEC \& MARIN-MORALES MA. 2009. Origin of nuclear and chromosomal alterations derived from the action of an aneugenic agente-Trifluralin herbicide. Ecotox Environ Saf 72: 1680-1686.

FERNANDEZ-BEDMAR Z \& ALONSO-MORAGA A. 2016. In vivo and in vitro evaluation for nutraceutical purposes of capsaicin, capsanthin, lutein and four pepper varieties. Food Chem Toxicol 98: 89-99.

FOFARIA NM, KIM S \& SRIVASTAVA SK. 2014. Piperine causes G1 phase cell cycle arrest and apoptosis in melanoma cells through checkpoint kinase-1 activation. PLoS ONE 9: $1-10$.

GREENSHIELDS AL, DOUCETTE DE, SUTTON KM, MADERA L, ANNAN H, YAFFE PB \& HOSKIN DW. 2015. Piperine inhibits the growth and motility of triple-negative breast cancer cells. Cancer Lett 357: 129-140.

GRINEVICIUS VMAS, ANDRADE KS, OURIQUE F, MICKE GA, FERREIRA SRS \& PEDROSA RC. 2017. Antitumor activity of conventional and supercritical extracts from Piper nigrum L. cultivar Bragantina through cell cycle arrest and apoptosis induction. J Supercritical Fluids 128: 94-101.

HUANG XF, XUE JY, JIANG AQ \& ZHU HL. 2013. Capsaicin and Its Analogues: Structure-Activity Relationship Study. Cur Med Chem 20: 2661-2672.

JIANG Y, SHAN S, CHI L, ZHANG G, GAO X, LI H \& YANG J. 2016. Methyl methanesulfonate induces necroptosis in human lung adenoma A549 cells through the PIG-3-reactive oxygen species pathway. Tumor Biol 37: 3785-3795. 
KAUR R \& ARORA S. 2015. Alkaloids-important therapeutic secondary metabolites of plant origin. J Crit Rev 2: 1-8.

KEHRER JP \& KLOTZ LO. 2015. Free radicals and related reactive species as mediators of tissue injury and disease: implications for health. Crit Rev Toxicol 45: 765-798.

LACKINGER D, EICHHORN U \& KAINA B. 2001. Effect of ultraviolet light, methyl methanesulfonate and ionizing radiation on the genotoxic response and apoptosis of mouse fibroblasts lacking c-Fos, p53 or both. Mutagen 16: 233-241.

LAI LH, FU QH, LIU Y, JIANG K, GUO QM, CHEN QY \& SHEN JG. 2012. Piperine suppresses tumor growth and metastasis in vitro and in vivo in a $4 \mathrm{~T} 1$ murine breast cancer model. Acta Pharmacol Sinica 33: 523-530.

LEME DM \& MARIN-MORALES MA. 2009. Allium cepa test in environmental monitoring: A review on its application. Mut Res 682: 71-81.

LI H, KRSTIN S, WANG S \& WINK M. 2018. Capsaicin and piperine can overcome multidrug resistance in cancer cells to doxorubicin. Molecules 23: 1-11.

LIU H, LIGHTFOOT R \& STEVENS JL. 1996. Activation of heat shock factor by alkylating agents is triggered by glutathione depletion and oxidant of protein thiols. J Biol Chem 271: 4805-4812.

LUO XJ, PENG J \& LI YJ. 2011. Recent advances in the study on capsaicinoids and capsinoids. Europe J Pharmacol 650: 1-7.

MACÁKOVÁ K, AFONSO R, SASO L \& MLADĚNKA P. 2019. The influence of alkaloids on oxidative stress and related signaling pathways. Free Rad Biol Med 134: 429-444.

MEGHWAL M \& GOSWAMI TK. 2013. Piper nigrum and piperine: An update. Phytoth Res 27: 1121-1130.

MUHAMMAD A, IBRAHIM MA, ERUKAINURE OL, MALAMI I \& ADAMU A. 2018. Spices with Breast Cancer Chemopreventive and Therapeutic Potentials: A Functional Foods BasedReview. Anti-Canc Ag Med Chem 18: 182-194.

NANTES CI, PESARINI JR, MAURO MO, MONREA ACD, RAMIRES AD \& OLIVEIRA RJ. 2014. Evaluation of the antimutagenic activity and mode of action of carrageenan fiber in cultured meristematic cells of Allium cepa. Gen and Mol Res 13: 9523-9532.

OUYANG DY, ZENG LH, PAN H, XU LH, WANG Y, LIU KP \& HE $X H$. 2013. Piperine inhibits the proliferation of human prostate cancer cells via induction of cell cycle arrest and autophagy. Food Chem Toxicol 60: 424-430.
PRAMANIK KC, BOREDDY SR \& SRIVASTAVA SK. 2011. Role of mitochondrial electron transport chain complexes in capsaicin mediated oxidative stress leading to apoptosis in pancreatic cancer cells. PLOS ONE 6: 1-16.

QIAN K, WANG G, CAO R, LIU T, QIAN G, GUAN X \& WANG X. 2016. Capsaicin suppresses cell proliferation, induces cell cycle arrest and ros production in bladder cancer cells through FOXO3a-Mediated pathways. Molecules 21: 1-15.

QU H, LV M \& XU H. 2015. Piperine: Bioactivities and Structural Modifications. Rev Med Chem 15: 145-156.

RATHER RA \& BHAGAT M. 2018. Cancer chemoprevention and piperine: molecular mechanisms and therapeutic opportunities. Front Cell Develop Biol 6: 1-12.

RAZA H. 2011. Dual localization of glutathione S-transferase in the cytosol and mitochondria: implications in oxidative stress, toxicity and disease. FEBS J 278: 4243-4251.

RIBEIRO D, FREITAS M, SILVA AM, CARVALHO F \& FERNANDES E. 2018. Antioxidant and pro-oxidant activities of carotenoids and their oxidation products. Food Chem Toxicol 120: 681-699.

ROCHA RS, KASSUYA CAL, FORMAGIO ASN, MAURO MDO, ANDRADE-SILVA M, MONREAL ACC \& OLIVEIRA RJ. 2016. Analysis of the anti-inflammatory and chemopreventive potential and description of the antimutagenic mode of action of the Annona crassiflora methanolic extract. Pharm Biol 54: 35-47.

SÁ IS, PERON AP, LEIMANN FV, BRESSAN GN, KRUM BN, FACHINETTO R \& GONÇALVES OH. 2019. In vitro and in vivo evaluation of enzymatic and antioxidant activity, cytotoxicity and genotoxicity of curcumin-loaded solid dispersions. Food Chem Toxicol 125: 29-37.

SALAZAR D, JARAMILLO MA \& MARQUIS RJ. 2016. Chemical similarity and local community assembly in the species rich tropical genus Piper. Ecology 97: 3176-3183.

SANTOS FJB, MOURA DJ, PÉRES VF, SPEROTTO ARM, CARAMÃO EB, CAVALCANTE AA \& SAFFI J. 2012. Genotoxic and mutagenic properties of Bauhinia platypetala extract, a traditional Brazilian medicinal plant. J Ethnopharmacol 144: 474-482.

SIDDIQUI S, AHAMAD MS, JAFRI A, AFZAL M \& ARSHAD M. 2017. Piperine triggers apoptosis of human oral squamous carcinoma through cell cycle arrest and mitochondrial oxidative stress. Nutr Cancer 69: 791-799.

SIDDIQUE YH, AKHTAR S, ANSARI MS, SHAKYA B, JYOTI S \& NAZ F. 2019. Protective effect of Luteolin against methyl methanesulfonate-induced toxicity. Toxin Rev 1-12. 
SINGH A \& DUGGAL S. 2009. Piperine - Review of Advances in Pharmacology Apoptosis inhibition. Internat J Pharm Sci Nanotechnol 2: 615-620.

SINGH IP \& CHOUDHARY A. 2015. Piperine and Derivatives: Trends in Structure-Activity Relationships. Current Top Med Chem 15: 1722-1734.

SOUTAR DA, DOUCETTE CD, LIWSKI RS \& HOSKIN DW. 2017. Piperine, a pungent alkaloid from black pepper, inhibits B lymphocyte activation and effector functions. Phyt Res 31: 466-474.

THIEL A, BUSKENS C, WOEHRLE T, ETHEVE S, SCHOENMAKERS A, FEHR M \& BEILSTEIN P. 2014. Black pepper constituent piperine: Genotoxicity studies in vitro and in vivo. Food Chem Toxicol 66: 350-357.

TSOI B, YI RN, CAO LF, LI SB, TAN RR, CHEN M \& HE RR. 2015. Comparing antioxidant capacity of purine alkaloids: $A$ new, efficient trio for screening and discovering potential antioxidants in vitro and in vivo. Food Chem 176: 411-419.

VURMAZ A, DUMAN R, SABANER MC, ERTEKIN T \& BILIR A. 2019. Antioxidant effects of piperine in in-vivo chick embryo cataract model induced by steroids. Cut Ocular Toxicol 38: 1-26.

WATERS MD. 1990. Antimutagenicity profiles for some model compounds. Mut Res 238: 57-85.

WONGPA S, HIMAKOUN L, SOONTORNCHAI S \& TEMCHAROEN P. 2007. Antimutagenic effects of piperine on cyclophosphamide induced chromosome aberrations in rat bone marrow cells. Asian Pacif J Cancer Prev 8: 623-627.

YAFFE PB, DOUCETTE CD, WALSH M \& HOSKIN DW. 2013. Piperine impairs cell cycle progression and causes reactive oxygen species-dependent apoptosis in rectal cancer cells. Exp Mol Pathol 94: 109-114.

ZHANG J, ZHU X, LI H, LI B, SUN L, XIE T \& YE Z. 2015. Piperine inhibits proliferation of human osteosarcoma cells via G2/M phase arrest and metastasis by suppressing MMP2/-9 expression. Int Immunopharmacol 24: 50-58.

\section{How to cite:}

DIAS MS, JUNIOR EPV, DOS SANTOS BC, MARTINS FA, DE ALMEIDA PM \& PERON AP. 2021. Cytogenotoxicity and protective effect of piperine and capsaicin on meristematic cells of Allium cepa L. An Acad Bras Cienc 93: e20201772. DOI 10.1590/0001-3765202120201772.

Manuscript received on November 12, 2020;

accepted for publication on March 2, 2021

\section{MARCONDES S. DIAS}

https://orcid.org/0000-0002-1434-3384

ERASMO P.V. JUNIOR ${ }^{2}$

https://orcid.org/0000-0002-7538-3822

\section{BIANCA C. DOS SANTOS ${ }^{2}$}

https://orcid.org/0000-0003-3154-3254

FRANCIELLE A. MARTINS ${ }^{2}$

https://orcid.org/0000-0002-0113-8023

PEDRO M. DE ALMEIDA ${ }^{2}$

https://orcid.org/0000-0001-5431-6818

ANA P. PERON ${ }^{3}$

https://orcid.org/0000-0003-2598-2621

1Programa de Pós-Graduação em Genética e Melhoramento, Universidade Federal do Piauí / UFPI, Laboratório de Genética, Ininga, 64049-550 Teresina, PI, Brazil

${ }^{2}$ Universidade Estadual do Piauí, Centro de Ciências Naturais (CCN), Laboratório de Genética, Rua João Cabral, 2231, 64002-150 Teresina, PI, Brazil

${ }^{3}$ Universidade Federal de Tecnologia, Paraná / UTFPR, Departamento de Biodiversidade e Conservação da Natureza, Campus Campo Mourão, Via Rosalina Maria dos Santos, 1233, Caixa Postal 271, 87301-899 Campo Mourão, PR, Brazil

Correspondence to: Pedro M. de Almeida

E-mail:pedromarcos@ccs.uespi.br

\section{Author contribuitions}

Marcondes Soares Dias conducted the entire study, analysis and interpretation of data and writing of the manuscript. Erasmo Pereira do Vale Junior and Bianca Cristina dos Santos participated in the analysis and interpretation of the data. Francielle Alline Martins contributed to the discussion and text review and Ana Paula Peron, co-supervised the research, was responsible for the study design and review. Pedro Marcos de Almeida participated in all stages from the idealization and design of the study, as well as analysis, review and interpretation of data.

\section{(cc) BY}

